\title{
AUTHOR'S ACKNOWLEDGEMENTS
}

I wish to express my gratitude to all those who assisted me in writing this book, especially Jacques Frayssenge, Nicolas Fornerod and Myriam Yardeni. I also wish to thank Ran Halévi for his careful reading of the manuscript, as well as Philippe Bernier.

Arlette Jouanna 
Arlette Jouanna - 9781526112194

Downloaded from manchesterhive.com at 04/26/2023 06:35:11AM via free access 